\title{
Editorial: The development of hydrogeological knowledge for contaminated-site remediation
}

Richard Jackson PhD, PEng, FGC(Hon)

Fellow, Geofirma Engineering; Adjunct Professor, Earth \& Environmental

Sciences, University of Waterloo, Canada

Some years ago, Kerry Rowe of Queen's University in Canada recounted the evolution of geoenvironmental engineering (Rowe, 2015) in this journal. He pointed out that engineered containment of hazardous wastes had evolved from compacted clay liners to geosynthetic clay liners during the late twentieth century. These would ensure that contaminant migration through the liners to the water table would only occur by diffusion. $\mathrm{He}$ also observed that the remediation of hazardous waste sites 'has been ongoing challenge'.

This short editorial presents an account of the legacy of hazardouswaste sites created by waste disposal in the years before the control of hazardous wastes was recognized as being critical to environmental protection. Even following the recognition of contaminated groundwater migrating from old dumpsites, the spill of solvents and fuels has raised additional problems of environmental remediation. Many geoenvironmental engineers have found themselves drawn into the clean-up of such contaminated sites with little geoscientific background with which to deal with the challenges they then face.

Consequently, my experience across North America over the past 50 years caused me to develop a textbook on the applied earth sciences (Jackson, 2019) written for geotechnical and geoenvironmental engineers wrestling with the uncertainties of heterogenous soils and bedrock discontinuities as they attempt to both understand the nature of the geological subsurface in their general practice and, more specifically, to understand the migration of miscible and immiscible contaminants within it.

Disposal of hazardous wastes - both intentional and unintentional - has of course a very long history. As the chemical and metal fabricating industries developed, little thought was given to appropriate treatment and/or disposal of industrial wastes. This changed at the end of World War II with the development of nuclear energy and the fabrication of nuclear weapons. In this case, it was quite obvious that the toxicity of these wastes produced required the most careful handling and disposal.

However, much aqueous radioactive waste was discharged to the shallow subsurface before the 1970s and geoscientists and engineers were charged with mapping and controlling the migration of these waste plumes. My colleagues and I have discussed the contribution of one such geotechnical engineer - Peter Parsons - to developing high-resolution soil mapping of strontium-90 $\left({ }^{90} \mathrm{Sr}\right)$ plumes at the Chalk River Nuclear Laboratories in Canada. We believe (Neville et al., 2018) that similar such studies at nuclear facilities laid the foundations of contaminant hydrogeology, the scientific enquiry into the migration and fate of contaminants in the subsurface.

These early studies identified the importance of the following.

(a) Contaminant dispersion in the field as opposed to that measured in laboratory soil columns (Theis, 1963).

(b) Radionuclides as groundwater tracers and indicators of subsurface residence times (Carlson, 1960)

(c) Contaminant retardation by sorption to soil surfaces - for example Jackson and Inch (1983) and references therein.

Each of these processes could only be understood by appreciating its geoscientific basis from a hydrogeological perspective.

The first article of this issue of Environmental Geotechnics illustrates how these processes have affected the migration of caesium-137 in soils contaminated by the Fukushima nuclear disaster of 2011 (Inazumi et al., 2019) and the numerical simulation of its seepage to assist in decontamination projects. The second article of this issue concerns the geochemical-mineralogical reactions occurring during a 15-year long experiment conducted to simulate nuclearwaste disposal with the waste surrounded by cementitious backfill. The modeling evaluated the evolution of minerals and pore fluids in contact with a hyperalkaline plume produced by the backfill (Chen and Thornton, 2019).

By the 1970s, the emergent environmental movement pointed to the inadequate nature of unlined municipal and industrial solid-waste disposal sites and of the plumes of 'leachate' emanating from them into the surrounding soils and aquifers (Baedecker and Back, 1979; Cherry, 1983). Thus, the 'sanitary landfill' was born and compacted clay liners soon adopted. Networks of leachate extraction wells formed pump-and-treat systems to both capture the plumes and protect nearby water wells. This need stimulated the requirement for understanding groundwater flow patterns and hydraulic properties so that the volume of uncontaminated groundwater drawn into and treated by the wells was minimized.

Plumes of landfill leachate and radionuclides (e.g., ${ }^{90} \mathrm{Sr}$ ) were early examples of miscible contaminants - that is those that readily dissolved in water or were discharged as aqueous wastes. Groundwater transport studies were the topic of greatest interest in the 1970 s as the lessons learned were applied to the investigation of the role of heterogeneities in soils arising from sedimentary deposition processes. A scale effect was noted in dispersion 
(Gelhar, 1986; Pickens and Grisak, 1981) that was difficult to explain other than by the effects of sample dilution in low-resolution mapping or from the cumulative effects of granular heterogeneities over longer distances. Gillham et al. (1984) proposed a model of contaminant advection in granular soils coupled with diffusion into low-permeability regions of these sedimentary structures that would combine to disperse the contaminant plumes over large distances.

However, by 1980 a new era of analytical chemistry had exposed the presence of a multitude of toxic organic chemicals dissolved in groundwaters across North American and Europe (Council on Environmental Quality, 1981). These chemicals had been dissolved from non-aqueous liquids (NAPLs) that were either fuels or solvents and, even at concentrations of $10 \mathrm{ppb}(\mu \mathrm{g} / \mathrm{L})$, exceeded the drinking water guidelines of the US Environmental Protection Agency and the World Health Organization. The fuels were typically referred to as LNAPLs, because their densities were lighter than groundwater, while chlorinated solvents were referred to as DNAPLs, being denser than groundwater. Ahmed and Abduljauwad (2019) describe in this issue how soil contamination by fuels alters the geotechnical properties of clays by creating oil-coated agglomerates that they characterize with molecular-level simulations.

Although these fuels and solvents had long been essential to industrial societies, their discovery dissolved in groundwater at toxic concentrations was a shock to those societies, which had previously focused on nitrate, road salt and bacterial contamination of groundwater (Council on Environmental Quality, 1981). It appeared that neither industry nor government agencies nor universities had conducted research before 1980 on the migration and fate of NAPLs in the subsurface.

There are four reasons explaining this absence of research.

(a) Many of these compounds were considered merely workplace hazards not drinking-water carcinogens.

(b) Neither monitoring wells sited near contamination sources nor analytical chemical methods were available to identify these problems until the late $1970 \mathrm{~s}$.

(c) There were no technical guiding paradigms in textbooks that would inform engineers and geoscientists how such groundwater contaminants migrate.

(d) These three factors interacted in a way that inhibited issue recognition and research of NAPLs until their dissolved solutes were detected by newly developed analytical chemical methods in the late 1970s (Jackson, 2004).

Once the problem was identified and regulations enacted (e.g. Superfund and RCRA in the USA), site investigations and academic research followed quickly. It was soon determined that lowviscosity fuels, such as gasoline, could in most cases be easily mapped in the subsurface. These fuels and the aqueous plumes they generated were remediated by soil-vapour extraction techniques. Low-viscosity but dense NAPLs (DNAPLs) presented a much more difficult characterization problem because their migration depended on textural and stratigraphic heterogeneities in the subsurface (Schwille, 1988). Furthermore, not only was DNAPL contamination difficult to characterize, the remediation of DNAPL source zones was problematic and many turned to methods of petroleum recovery for remediation (e.g. chemical and thermal techniques) as well as soil-vapour extraction (Kaluarachchi, 2001; National Research Council, 2005). Some DNAPLs, such as coal tar and creosote, were so viscous as to appear to be stationary in the subsurface but proved to be mobile and exceptionally persistent (Jackson et al., 2006).

A particular feature of many contaminant plumes observed during the 1980s was the naturally-occurring biodegradation of many toxic organic compounds. Under aerobic conditions, in which dissolved oxygen was present in groundwater, dissolved fuel hydrocarbons such as benzene and toluene would readily biodegrade. Under anaerobic conditions, in which oxygen had already been consumed, various dissolved chlorinated compounds would undergo dechlorination. From this evidence, the concept of natural attenuation developed such that, if source zones of NAPLs were remediated to the extent practicable, contaminant plumes were allowed to develop and degrade naturally (National Research Council, 2000).

Although this development was observed in the 1980s in North America as plumes were mapped, natural attenuation of leachate had been discovered earlier by German hydrogeologists (Matthess, 1972; Schwille, 1976), who had described the various physicalchemical processes that resulted in 'the self-purification' of contaminated groundwater. It was subsequently pointed out by Champ et al. (1979) that self purification was the result of thermodynamically-controlled chemical reactions dictated either by an excess of dissolved organic carbon or dissolved oxygen within a plume. These microbially-assisted redox processes could be relied upon to produce attenuation of many toxic organic chemicals within contaminant plumes (e.g. benzene, trichloroethene).

In recent years, there has been much interest in gas migration and behavior in the subsurface as a result of hydraulic fracturing, nuclear-waste management and mine-waste tailings disposal. Scale and Fleming (2019) in this issue of Environmental Geotechnics illustrate numerical simulation of advective and diffusive gas fluxes in soil covers associated with overburden from oil-sands mining to facilitate methane oxidation and oxygen availability. Finally, we present two articles that concern improving soil strength properties. The first, by Odumade et al. (2019) investigates the addition of various cements to laterite soils of differing $\mathrm{SiO}_{2}, \mathrm{Fe}_{2} \mathrm{O}_{3}$ and $\mathrm{Al}_{2} \mathrm{O}_{3}$ composition to improve soil strength and durability (e.g. hydraulic performance in areas of high precipitation). The second, by Keykha et al. (2019), concludes this issue and considers how the biogeochemical mechanisms associated with microbially-induced calcium carbonate precipitation can result in soil improvement (e.g. via increases in shear strength, UCS, etc.).

Interpreting these processes requires considerable insight into the nature of geological features that affect contaminant migration 
and attenuation. My experience in practice in North America from the 1970s onward indicated that a clearer understanding of these processes by geoenvironmental engineers would prevent the completion of inadequate or even incorrect site characterizations leading to increased remediation costs. As the late James Mercer wisely commented, 'successful remediation requires successful characterization'. It was with such motivation in my mind that Earth Science for Civil and Environmental Engineers was published by Cambridge University Press earlier this year (Jackson, 2019).

\section{REFERENCES}

Ahmed H-ur-R and Abduljauwad SN (2019) Molecular-level simulations of oil-contaminated clays. Environmental Geotechnics 6(8): 528-542, https://doi.org/10.1680.jenge.16.00032.

Baedecker MJ and Back W (1979) Hydrogeological processes and chemical reactions at a landfill. Groundwater 17(5): 429-437.

Carlston CW, Thatcher LL and Rhodehamel EC (1960) Tritium as a hydrologic tool-The Wharton tract study. General Assembly of Helsinki. Commission of Subterranean Waters, 503, p. 512.

Champ DR, Gulens J and Jackson RE (1979) Oxidation-reduction sequences in ground water flow systems. Canadian Journal of Earth Sciences 16(1): 12-23.

Chen X-H and Thornton S (2019) Multimineral reactions controlling secondary phase evolution in a hyperalkaline plume. Environmental Geotechnics 6(8): 521-527, https://doi.org/10.1680/jenge.17.00012.

Cherry JA (1983) Migration of contaminants in groundwater at a landfill: a case study. Journal of Hydrology 63(1-2): 1-197.

Council on Environmental Quality (US) (1981) Contamination of Ground Water by Toxic Organic Chemicals.

Gelhar LW (1986) Stochastic subsurface hydrology from theory to applications. Water Resources Research 22(9S): 135S-145S.

Gillham RW, Sudicky EA, Cherry JA and Frind EO (1984) An advection-diffusion concept for solute transport in heterogeneous unconsolidated geological deposits. Water Resources Research 20(3): 369-378.

Inazumi S, Hashida $\mathrm{H}$ and Ueyama $\mathrm{Y}$ (2019) Transportation behaviour of radioactive substances in soils. Environmental Geotechnics 6(8): 506-520, https://doi.org/10.1680/jenge.16.00024.

Jackson RE (2004) Recognizing emerging environmental problems: the case of chlorinated solvents in groundwater. Technology and Culture 45(1): 55-79.

Jackson RE (2019) Earth Science for Civil and Environmental Engineers. Cambridge University Press.
Jackson RE and Inch KJ (1983) Partitioning of strontium-90 among aqueous and mineral species in a contaminated aquifer. Environmental Science \& Technology 17(4): 231-237.

Jackson RE, Dwarakanath V, Ewing JE and Avis J (2006) Migration of viscous non-aqueous phase liquids (NAPLs) in alluvium, Fraser River lowlands, British Columbia. Canadian Geotechnical Journal 43(7): 694-703.

Kaluarachchi JJ (ed.) (2001) Groundwater Contamination by Organic Pollutants. American Society of Civil Engineers, ASCE Manuals and Reports on Engineering Practice No. 100.

Keykha HA, Asadi A, Huat BBK and Kawasaki S (2019) Microbial induced calcite precipitation by Sporosarcina pasteurii and Sporosarcina aquimarina. Environmental Geotechnics 6(8): 562-566, https://doi. org/10.1680/jenge.16.00009

Matthess G (1972) Hydrogeologic criteria for the self-purification of polluted groundwater. In Section 11 Hydrogeology, Proc. International Geological Congress, 24th Session, Montreal, Canada, pp. 296-304.

National Research Council (2000) Natural Attenuation for Groundwater Remediation. National Academies Press.

National Research Council (2005) Contaminants in the Subsurface: Source Zone Assessment and Remediation. National Academies Press.

Neville CJ, Jackson RE and Killey RD (2018) Peter J. Parsons: pioneer of contaminant hydrogeology. Hydrogeology Journal 26(2): 665-672.

Odumade AO, Ezeah C and Ugwu OO (2019) Performance analysis of cement-stabilised laterite for road construction in the tropics. Environmental Geotechnics 6(8): 555-561, https://doi.org/10.1680/ jenge.17.00026.

Pankow JF and Cherry JA (1996) Dense Chlorinated Solvents and Other DNAPLs in Groundwater: History, Behavior, and Remediation. Waterloo Press, Portland, OR, USA.

Pickens JF and Grisak GE (1981) Scale-dependent dispersion in a stratified granular aquifer. Water Resources Research 17(4): 1191-1211.

Rowe RK (2015) Reflections on the evolution of geoenvironmental engineering. Environmental Geotechnics 2(2): 65-67, https://doi. org/10.1680/envgeo.13.00105.

Scale KO and Fleming IR (2019) The role of pore-gas dynamics in guiding reclamation process. Environmental Geotechnics 6(8): 543-554, https://doi.org/10.1680/jenge.17.00030.

Schwille F (1976) Anthropogenically reduced groundwaters. Hydrological Sciences Journal 21(4): 629-645.

Schwille F (translated by Pankow JF) (1988) Dense Chlorinated Solvents in Porous and Fractured Media-Model Experiments. Lewis Publishers, Chelsea, MI, USA.

Theis CV (1963) Hydrologic phenomena affecting the use of tracers in timing groundwater flow. In Radioisotopes in Hydrology. Proceedings of a Symposium, Tokyo, Japan. 